\title{
甲状腺の自己免疫機序に関する臨床的研究
}

第 1 篇 甲状腺疾患者の血中サイログロブリン濃度の測定に関する研究

京都大学医学部放射線科（指導：鳥塚莞爾教授）

池窪勝治

\section{Clinical Studies on Autoimmune Mechanisms of the Thyroid}

Part I. Studies on Measurements of Serum Thyroglobulin Concentrations in Patients with Various Thyroid Diseases.

\section{Katsuji IKEKUBO}

Department of Radiology, Kyoto University School of Medicine, Kyoto, Japan.

(Director : Professor Kanji Torizuka)

The present report deals with the measurement of serum thyroglobulin $(\mathrm{Tg})$ in various thyroid disorders by using radioimmunoassay (RIA). The results were as follows :

1) A specific and simple solid-state RIA for the measurement of $\mathrm{Tg}$ in human serum was used. This system was a direct RIA using plastic cups coated with crude anti-thyroglobulin antibodies (anti-Tg) and ${ }^{125} \mathrm{I}$ labeled purified anti-Tg. The purification of anti-Tg was performed by affinity chromatography using $\mathrm{Tg}$-Sepharose, as an immunoadsorbent.

2) Affinity chromatography was carried out using a modification of the method of Cuatrecasas. The immunoadsorbent (Tg-Sepharose conjugate) was used in a column procedure for the isolation of anti-Tg from globulin fractions obtained from Hashimoto's sera. The elution was performed with $4 \mathrm{M} \mathrm{NaI}$ or $0.17 \mathrm{M}$ Glycine- $\mathrm{HCl}$ with $\mathrm{pH} 2.3$. The eluted materials contained a very small amount of $\mathrm{Tg}$ which was removed by Sephadex G-200 chromatography using the same elution buffer. The high purity of the anti-Tg obtained was demonstrated by the fact that almost all of the final product was bound with $\mathrm{Tg}$ by using Sephadex G-200 chromatography.

3) A direct RIA consisting of two incubation steps was applied for Tg measurement. During the first incubation, standard $\mathrm{Tg}$ or $\mathrm{Tg}$ in serum was bound to the antibody coated cup. After washing, equal amounts of radioactive purified anti-Tg were incubated with the bound Tg. The cups were then washed again, and counted separately. The radioactive counts thus obtained, increased with the amounts of $\mathrm{Tg}$ bound to the anti-Tg by the first incubation.

The sensitivity of the assay was $4 \mathrm{ng} / \mathrm{ml} . \mathrm{T}_{3}$ and $\mathrm{T}_{4}$ did not cross-react against $\mathrm{Tg}$, and did not interfere with the binding between $\mathrm{Tg}$ and ${ }^{125} \mathrm{I}$-anti-Tg. A dilution curve was constructed using the serum of a patient with Graves' disease; the post-operative 
serum contained a very high level of $\mathrm{Tg}$. This curve paralleled the standard curve. By adding constant $\mathrm{Tg}$ to a normal serum or Graves' serum, Tg recovery was good. However, in regard to Hashimoto's serum, Tg recovery was unsatisfactory.

4) Serum Tg concentrations were measured in patients with various thyroid disorders. Tg was detectable in $60 \%$ of 25 normal subjects tested, with an average level of $26.5 \pm 26.5$ $($ mean $\pm \mathrm{SD}) \mathrm{ng} / \mathrm{ml}$. Serum concentrations in 23 simple goiter, 9 untreated Graves' disease, 27 treated Graves' disease, 10 Hashimoto's thyroiditis having undetectable anti-Tg, 13 adenoma and 8 thyroid cancer were measured as $37.9 \pm 87.0 \mathrm{ng} / \mathrm{ml}, 324.3 \pm 517.8 \mathrm{ng} / \mathrm{ml}$, $71.0 \pm 138.6 \mathrm{ng} / \mathrm{ml}, 172.5 \pm 314.5 \mathrm{ng} / \mathrm{ml}, 126.0 \pm 146.0 \mathrm{ng} / \mathrm{ml}$ and $15.0 \pm 14.1 \mathrm{ng} / \mathrm{ml}$, respectively. In two patients with subacute thyroiditis, one patient had $100 \mathrm{ng} / \mathrm{ml}$ and the other gave a value of $280 \mathrm{ng} / \mathrm{ml}$.

In patients with Graves' disease, there was no correlation between $\mathrm{Tg}$ concentration and $\mathrm{T}_{3}$ and $\mathrm{T}_{4}$. In two patients with Graves' disease undergoing partial thyroidectomy, serum $\mathrm{Tg}$ levels went up $16-30 \mu \mathrm{g} / \mathrm{ml}$ after the surgery. A patient with thyroid cancer showed a serum $\mathrm{Tg}$ value of $350 \mathrm{ng} / \mathrm{ml}$ after total thyroidectomy.

5) High Tg levels were observed mostly in patients with low titers of anti-Tg. However, even with the existence of potent anti-Tg, Tg could be detected in some instances. It seemed that these $\mathrm{Tg}$ values represented free $\mathrm{Tg}$ concentration when used in the present direct RIA system.

\section{I 緒文}

甲状腺からの流出抗原であるサイログロブリン（thyroglobulin, Tg）が甲状腺の自己免疫機序に聒いて， 抗原としてぞのよら飞関与しているかは興味が持たれる. 著者は甲状腺自己免疫機序の一端の解明のため各 種甲状腺疾患者の血中 $\mathrm{Tg}$ 濃度の測定を意図した。人の血中に $\mathrm{Tg}$ の存在することは, 既に Lerman ${ }^{1)} ら 以$

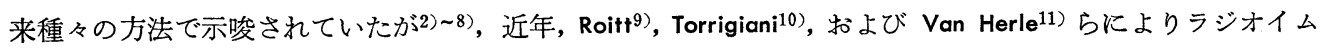
ノアッセイ (radioimmunoassay, RIA) を用いての正常者および甲状腺疾患者の血中 Tg 濃度の測定が報 告されている.しかしながら, これらの RIA は2 抗体法であり, したがって, 患者血中に抗サイログロブ リン抗体 (antithyroglobulin antibodies, anti-Tg) が存在する場合, 標識 $\mathrm{Tg}$ は系内の添加抗体 (抗七ト

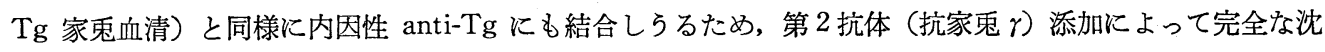
澱を示さず，見かけ上は Tg 高值を示すことになる.したがって，2 抗体法で RIA を行なった報告では， すべて anti-Tg を有しない患者の及を対象としている10),11)。乙かしながら自己兔疫的甲状腺疾患である橋

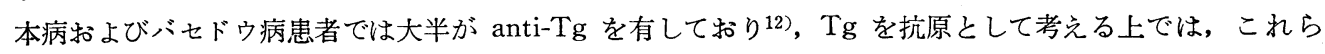
疾患時の $\mathrm{Tg}$ 濃度測定がより大きな意義があると考兄られる.この目的のために著者は直接法による固相 法 RIA を開発して，Tg の测定を試み，その臨床応用を行ならと共に，anti-Tg の存在下における Tg 濃 度についても若干の知見を得た：をた本 RIA 開発の途上，anti-Tg の精製の必要性を認め, Immunoadsorbent による高純度抗体の精製を行なった. 以下, これらの成績について述べる.

\section{II 測 定 原 理}

Tg 濃度の測定は plastic microtiter plate を用いた固相法 RIA によった. 
原理はプラスチック表面に非特異的に結合せしめた抗体（固相）と Tg との抗原抗体反応にもとづくる のである.著者はまず，抗体 (固相に吸着) に対する標識 $\mathrm{Tg}$ と非標識 $\mathrm{Tg}$ の競合的結合反応を利用した $\mathrm{Tg}$ 測定 (間接法)を試みたが，十分な感度が得られず，再現性もそしかった。したがって第 1 段階とし て, まず, 固相に吸着させた抗体と非標識（標準物質または被検血清）を結合させ，第 2 段階ではこれに標 識した精製 anti-Tg を結合させて, Tg 量に相応した放射能量を得ることにより Tg 量を測定する直接法 RIA を検討した．本法による測定のためには純度の高い anti-Tg の精製が必要であり、これを Immunoadsorbentを用いた affinity chromatography により行なった。

\section{III 実 験 材 料}

\section{1) 抗原 ( $\mathbf{T g}$ ) 精製}

甲状腺組織を 2 倍等量の $0.25 \mathrm{M}$ 蔗糖でホモゲナイズし, 順次, $2,000 \mathrm{rpm}, 20$ 分間, $8,000 \times \mathrm{g}, 20$ 分間, 更に $4^{\circ} \mathrm{C}, 105,000 \times \mathrm{g}, 60$ 分間の超遠沈 (Spinco model, 日立 $55 \mathrm{PA}$ ) そて甲状腺の可溶性蛋白を得た。 の $5 \mathrm{ml}(50 \sim 80 \mathrm{mg} / \mathrm{ml}$ 蛋白濃度 $)$ を $2.5 \times 100 \mathrm{~cm}$ のセファデックス $\mathrm{G}-200$ カラムにて, $0.02 \mathrm{M}$, リン 酸緩衝食塩液, PH7.6 で溶出し, その第 1 溶出分画を更に濃縮後, 再クロマトグラフィし, 再び超遠沈し て精製 Tg を得た. 精製蛋白は滤紙電気泳動法 ${ }^{13)}$, 抢よび免疫電気泳動法 ${ }^{14)}$ により inter- $\alpha$ の泳動度を示 す単一成分であり, 抗全ヒト血清とは反応せず, Tg に対する沈降抗体陽性の橋本病患者血清と反応した.

2) 抗体

Ouchterlony 法 ${ }^{15)}$ とより Tg と沈降抗体強陽性を示す橋本病患者血清拉よびこの IgG 分画を抗体とし て使用した. IgG 分画は血清の $45 \%$ 飽和硫安沈洪分画を $0.005 \mathrm{M}$, リン酸緩衝液, PH 7.8 を用い, DEAE セルロースカラムクロマトグラフィにより精製した。

\section{3) 実験対象}

正常人は京大病院勤務者の中から内分泌機能異常を認めない者を選び, 各種甲状腺疾患者は京大病院外来 および入院患者で臨床的，機能検査拉よび甲状腺針生検などにより診断の確定したものを対象とした。

\section{N 実 験 方 法}

\section{1） Immunoadsorbent による anti-Tg の精製}

Cuatrecasas ${ }^{16)}$ に準じた. すなわち, 先ず Table 1 に示す如く, CNBr-activated Sepharose 4B (Pharmacia）に Tg を加えて結合させた. 基礎的検討として， ${ }^{125} \mathrm{I}-\mathrm{Tg}$ をトレーサーとして用い，その結合をみた 結果, 24時間で, セファローズ $1 \mathrm{ml}$ につき $1.4 \sim 2.9 \mathrm{mg}$ の Tg の結合が得られた. したがって, セファロ 一ズ・ゲルの $1 \mathrm{ml}$ につき $3 \sim 4 \mathrm{mg}$ の $\mathrm{Tg}$ を使用した. 次に $\mathrm{Tg}$ 一七ァローズ結合物をカラムに充てん し, 緩衝液で洗滌して未結合の Tg を除去した. エタノールアミンによる処理後は溶出液と出発緩衝液で 交互に $2 \sim 3$ 回洗滌した.

次に抗体として沈降抗体陽性血清のグロブリン分画（45\%飽和硫安沈澱分画）をカラムにかけて出発緩衝 液で非吸着蛋白が完全に溶出されるまで洗滌した.

特異抗体の溶出は $0.17 \mathrm{M}$, Glycine- $\mathrm{HCl}$ 緩衝液 ( $\mathrm{G}-\mathrm{HCl}), \mathrm{pH} 2.3$ あるいは $4 \mathrm{M} \mathrm{NaI}$ を用いて行なった. 溶離液は直ちに蒸溜水で透析し, NaI を除去した. 両者共, 最終的には $0.01 \mathrm{M}$ リン酸緩衝食塩液 (PBS), PH 8.0 で透析し, 生じた沈澱は遠沈により除去した.

$\mathrm{G}-\mathrm{HCl}$ と NaI 処理による抗体価の変化をサイロイド・テストを用いて検討した.すなおち, 数種の抗体 含有患者血清に溶出液を $1: 5$ の比率で加えて, 24時間, $4^{\circ} \mathrm{C}$ に放置したが抗体価には何らの変化も認めな かった.

\section{2) $\mathbf{T g}$ 測定法}

プラスチック製 microtiter plate U 型 (Cooke 社製, 米国) の各カップを抗体稀釈液で满たし 2 時間, 室温に静置することで抗体はプラスチック表面に非特異的に吸着される (precoating). 内容を吸引除去後, 
Table 1. Purification Procedures of anti-Tg by affinity chromatography

1. Formation of $\mathrm{Tg}$-Sepharose conjugate

CNBr-activated Sepharose $4 \mathrm{~B}+\mathrm{Tg}(3-4 \mathrm{mg} / \mathrm{ml} \cdot$ sepharose $)$

dissolved in coupling buffer*

stirred 24 hrs. at $4^{\circ} \mathrm{C}$

2. Preparation of Column

Tg-Sepharose conjugate was packed in a column $(2 \times 20 \mathrm{~cm})$

Then, washed successively with

1) 10 volume of coupling buffer

2) $1 \mathrm{M}$ ethanolamine at $\mathrm{PH} 8.0$ for 2 hrs.

3) 10 volume of elution buffer**

4) 10 volume of starting buffer***

3. Application on the Column

Applied $600-3,000 \mathrm{mg}$ of globulin fractions of anti-Tg sera onto the column

Washed with starting buffer until unadsorbed protein was completely eluted

4. Elution

Eluted with elution buffer, and collected the first excluded protein peak

* $0.1 \mathrm{M}$ Carbonate-Bicarbonate buffer solution containing

$0.5 \mathrm{M} \mathrm{NaCl}, \mathrm{pH} 8.0 \sim \mathrm{pH} 9.0$

** $0.17 \mathrm{M}$ Glycine- $\mathrm{HCl} \mathrm{pH} 2.3$ or $4 \mathrm{M} \mathrm{Nal}$

*** 0.02M Phosphate buffer containing $0.5 \mathrm{M} \mathrm{NaCl}, \mathrm{pH} 8.0$

PBS, PH 7.2 で洗滌し, 次いで各カップを牛血清アルブミン (BSA) 溶液で満たし, カップ表面に残存す る空白結合部位を飽和させ (second coating), 10分後, 吸引除去する.これにインキュベイション・混合 物 $(0.25 \mathrm{ml})$ として, 間接法では ${ }^{125} \mathrm{I}-\mathrm{Tg}$ と標潐 $\mathrm{Tg}$ または被検血清, 直接法では第 1 段階で標準 $\mathrm{Tg}$ ま たは被検血清, 第 2 段階で ${ }^{125} \mathrm{I}$-anti-Tg を入れ， $4^{\circ} \mathrm{C}$ でインキュベイトした.インキュベイション後は内 容を吸引, 除去し, 水道水で洗滌後, 各カップを切り離してその放射能量を測定した. 抗体稀釈液としては $0.02 \mathrm{M}$ 炭酸重炭酸緩衝液, PH 9.6, second coating およびインキュベイション・混合物の溶媒としては BSA の $2 \%$ PBS 溶液, PH 7.2 を用いた。実験はすべて triplicate で行なった。

\section{a) 間接法}

アッセイ上, 至適な抗体稀釈度を求めるため種々の稀釈抗体で各カップを被覆後, ${ }^{125} \mathrm{I}-\mathrm{Tg}$ の一定量 $(5 \times$ $10^{4} \mathrm{cpm} / \mathrm{cup}$ )を加えて，抗体稀釈曲線を得た。これに基づき， IgG の3,000倍または血清の16,000倍抗体稀 釈液でカップを被徣し,インキュベイション・混合物として種々濃度の標淮 $\mathrm{Tg}$ と一定量の ${ }^{125} \mathrm{I}-\mathrm{Tg}(5 \times$ $\left.10^{4} \mathrm{cpm}\right)$ を用いて，24時間，インキュベイトした.

\section{b) 直接法}

第 1 段階でのインキュベイション・混合物として， $2 \% \mathrm{BSA}$ 飞各種濃度の標淮 Tg あるいは被検血清 $0.1 \mathrm{ml}$ を加えて $0.25 \mathrm{ml}$ とし, 24時間, インキュベイション後内容を除去し, 洗滌した. この段階では $\mathrm{Tg}$ はカップに吸着した抗体と結合し，非結合物は洗滌により除去される．第 2 段階としては， ${ }^{125}$ 標識精製 anti-Tg の一定量を加兄, 再度, 24時間のインキュベイション後, 内容を除去, 水洗後に各カップの放射能 量を測定した。基礎的検討としては, (1)抗体稀釈度 (2)インキュベイション時間 (3) ${ }^{125} \mathrm{I}-\mathrm{anti}-\mathrm{Tg}$ 量 (4)高 濃度 Tg 血清の稀釈曲線 (5)各種血清の添加 Tg の回収率 (6)標準 Tg 扣よび患者血清に対する anti-Tg の影響等につき検討した。 


\section{3) 標識}

Tg および anti-Tg の標識は Hunter-Greenwood の方法に準じた. 40〜50 $\mu$ g の Tg 岁るいは anti-Tg に $2 \mathrm{mci}$ の ${ }^{125 \mathrm{I}}$ (または ${ }^{131} \mathrm{I}$ ) を用いて標識し, セファデックス $\mathrm{G}-50$ カラムにて無機ヨードを分離し, 比 放射能 $20 \sim 30 \mu \mathrm{ci} / \mu \mathrm{g}$ のものを得た.

4) 血中抗甲状腺自己抗体の検出

血清中の anti-Tg はサイロイド・テスト(富士臟器 K.K.) を用いて測定した.

\section{$\mathrm{V}$ 実 験 成 績}

\section{1) anti-Tg 精製の affinity chromatography}

a) anti-Tg 溶出パターン

溶出液として $4 \mathrm{M} \mathrm{NaI}$ と $\mathrm{G}-\mathrm{HCl}$ を用いた場合, 両者共にほぼ同様の溶出パターンを示した. Fig. 1 に $4 \mathrm{M} \mathrm{NaI}$ のパターンを示す．また回収された精製抗体量は使用グロブリン量の $1.8 \%$ で，両溶出液間では ほとんど差が認められなかった。

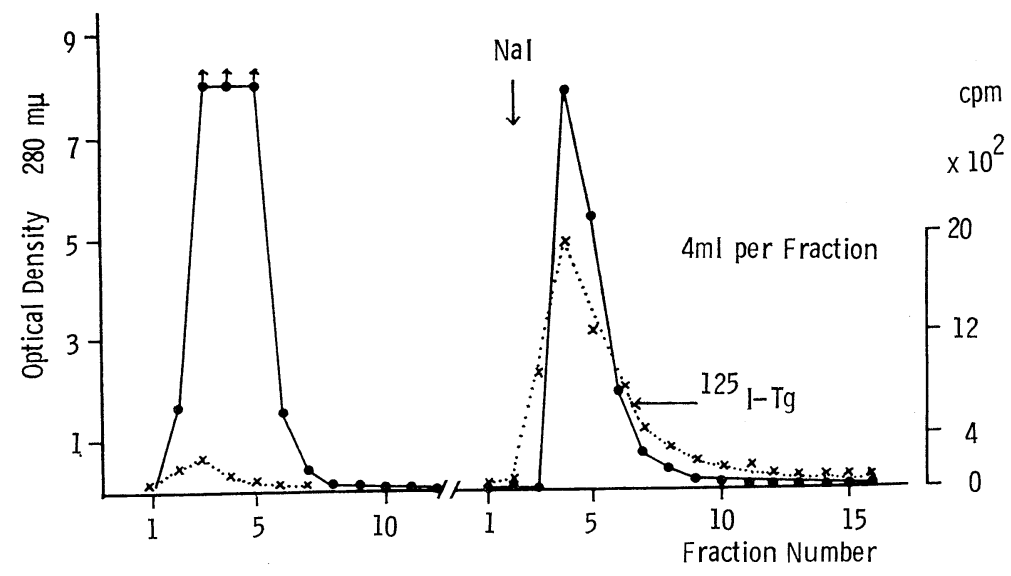

Fig. 1. Elution pattern of anti-Tg from a Tg-Sepharose column. The arrow indicates a start point of elution with $4 \mathrm{M} \mathrm{NaI}$.

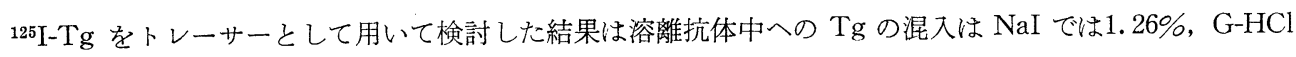
では $0.46 \%$ で両者共に極めて微量であった.

\section{b）精製 anti-Tg の純度の検定}

検定法の一つとして Cumulative binding technique を用いた。すなおち，精製 anti-Tgを ${ }^{125} \mathrm{I}$ (また は $\left.{ }^{131} \mathrm{I}\right)$ で標識し, これを高濃度 $(0.1 \mathrm{mg} / \mathrm{ml})$ の $\mathrm{Tg}$ (リン酸緩衝液, PH 6.4 を使用) で, あらかじめ 被覆したプラスチック試験管中で，軽く振動しながらインキュベイトし，30分後に内容物を同様に処理した 2 番目の試験管に移し, この過程を合計10回繰り返した.

Fig. 2 は各試験管に結合した放射能量を加算して標識物の何\%が Tg 飞結合しうるかを示したものであ る.成績は $\mathrm{NaI}$ と $\mathrm{G}-\mathrm{HCl}$ 使用時で差異を認めず，括括むね $37 〜 38 \%$ にとどまり，それ以上には上昇しな かった．更にこの精製蛋白を affinity chromatography により再クロマトグラフィしたが改善を認めなか った. 純度の低い原因としては Tg の混入，anti-Tg 以外のグロブリンの混入などが考学られ，溶出した 抗体をそのまま $4 \mathrm{M} \mathrm{NaI}$ 用いて更にセファデックス G-200でクロマトグラフィを行なった. Fig. 3 に 示す如く， a ， bの 2 相性を示した． a 分画は Tgに一致するピークであり，Tg の混大または Tg-anti$\mathrm{Tg}$ 複合体の存在が考兄られた。 $\mathrm{b}$ 分画を用いて純度検定を試みたが若干の上昇を認めたに過ぎなかった。 


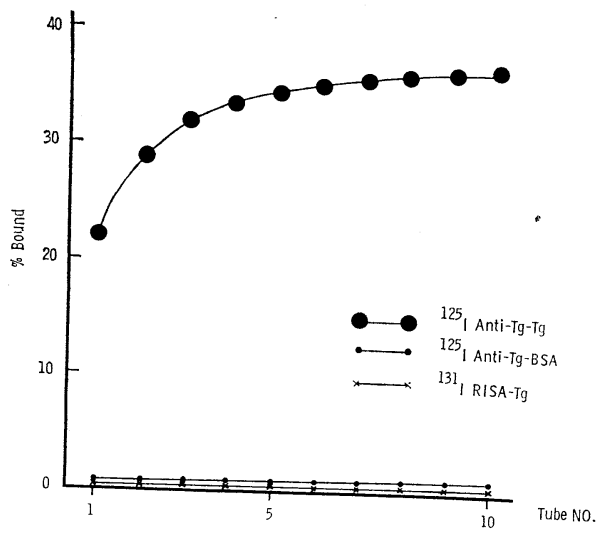

Fig. 2. Cumulative binding curve of labeled anti-Tg or ${ }^{131} \mathrm{I}$ Human serum albumin against $\mathrm{Tg}$ and Bovine serum albumin.

したがって，異なった純度検定法として，b分画 を禋識した ${ }^{125} \mathrm{I}$-anti-Tg と高濃度 $\mathrm{Tg} 4^{\circ} \mathrm{C}$, 48時 間, インキュベイト後, セファデックス G-200で クロマトグラフィを行なった. その結果は Fig. 4 の Aに示寸如く, 対照として Tg の代りに 1\%BSA と ${ }^{125} \mathrm{I}$-anti-Tgのインキュベート後にクロマトグラ フィして得られたピーク Bに比して明らかに早い大 分子の溶出を認め, Tg-anti-Tg 複合体の形成がう かがわれた、したがってこのb分画はかなり純度の 高い anti-Tg と考え, 以下これを用いて実験した.

2） Tg 測定法 (間接法)

\section{a) 抗体稀釈曲線}

種々稀釈抗体液にて各カップを被覆した後に ${ }^{125} \mathrm{I}-$ Tg の一定量 $\left(5 \times 10^{4} \mathrm{cpm} / \mathrm{cup}\right)$ を加兄ての結合は Fig. 5 の如く, 血清では, 最高38\%が結合し, 8,000 倍稀釈以上では，抗体の稀釈とともにその結合\%は 減少した.

$\operatorname{IgG}(1.7 \mathrm{mg} / \mathrm{ml})$ では, 最高 $32 \%$ が結合し, 1,000 倍稀釈以上で抗体の稀釈と共に，その結合\% は減少した。したがってその50\%結合を示す抗体稀 釈度を用いて，標準曲線を作成した。

\section{b）標準曲線}

抗体として血清の16,000倍, および IgG の3,000 倍を用いて作成した標準曲線は Fig. 6 の如くであ る. 抗体として IgG を用いた場合は感度が悪く, 血清を用いた場合 $3.1 \mathrm{ng} / \mathrm{cup}$ の感度であった. 被

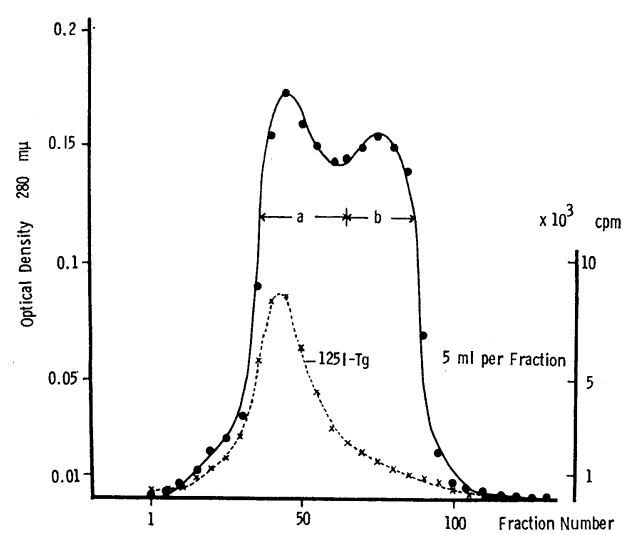

Fig. 3. Rechromatographic fractionation of the elute(purified anti-Tg by affinity chromatography) on Sephadex G-200 using $4 \mathrm{M} \mathrm{NaI}$ as elution buffer.

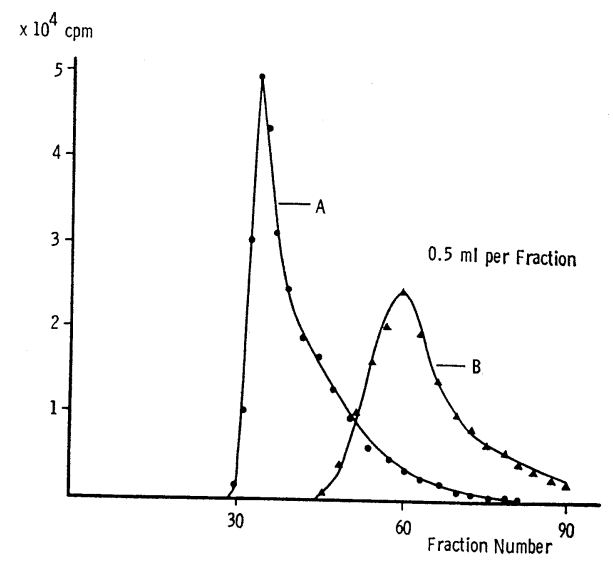

Fig. 4. Fractionation of ${ }^{125} \mathrm{I}-a n t i-T g$ incubated with $\operatorname{Tg}(\mathrm{A})$ or $\mathrm{BSA}(\mathrm{B})$ by gelfiltration on Sephadex G-200.

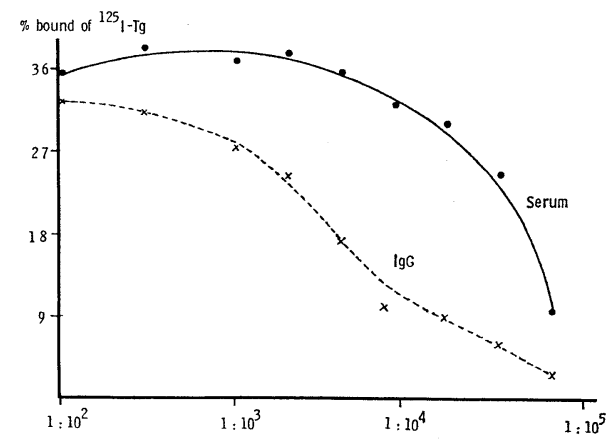

Fig. 5. Antibody dilution curves. 


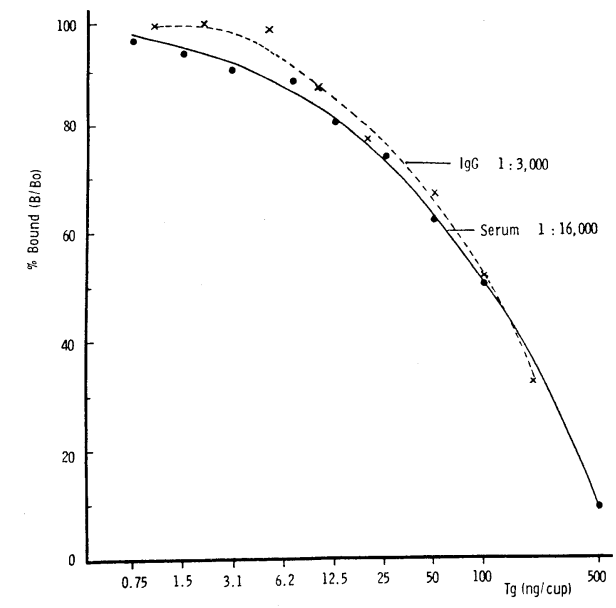

Fig. 6. Standard curve for Tg radioimmunoassay (Indirect method).

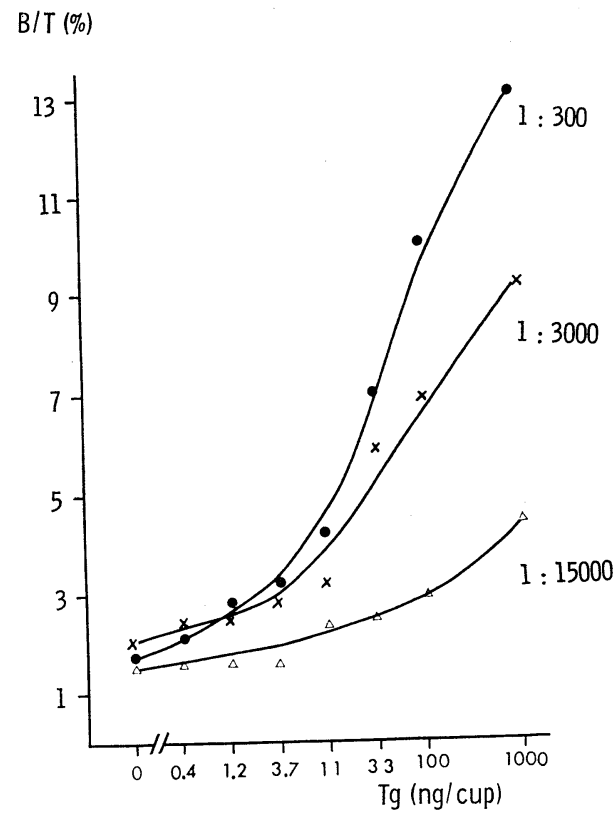

Fig. 7. Standard curves for Tg radioimmunoassay obtained by various precoating antibody concentrations.

Table 2. Effect of incubation time on the binding of ${ }^{125} \mathrm{I}-\mathrm{anti}-\mathrm{Tg}$

1) The first incubation time

Cups were precoated with $1: 300$ dilution of crude anti-Tg serum and the first incubations were performed for 16 and 24 hours under existence of various concentration of standard Tg. The second incubation with ${ }^{125} \mathrm{I}-\mathrm{Tg}$ was kept constant for 24 hours.

Added Tg Concentration (ng/assay)

\begin{tabular}{l|lllrl} 
& 0 & 1.5 & 25 & 100 & 1,000 \\
\hline $16 \mathrm{hr}(\mathrm{B} / \mathrm{T}) \%$ & 1.6 & 2.6 & 4.4 & 8.2 & 11.3 \\
$24 \mathrm{hr}(\mathrm{B} / \mathrm{T}) \%$ & 1.5 & 2.8 & 6.4 & 10.2 & 12.5
\end{tabular}

2) The second incubation time

Similar as the above, but the first incubation was kept for 24 hours and the second incubation time was changed from 6 to 48 hours.

Added Tg Concentration (ng/assay)

\begin{tabular}{r|llcr} 
& 0 & 4.1 & 12.3 & 1,000 \\
\hline $6 \mathrm{hr}(\mathrm{B} / \mathrm{T}) \%$ & 0.8 & 2.2 & 3.4 & 8.8 \\
$12 \mathrm{hr}(\mathrm{B} / \mathrm{T}) \%$ & 1.5 & 3.1 & 4.4 & 11.1 \\
$24 \mathrm{hr}(\mathrm{B} / \mathrm{T}) \%$ & 1.9 & 4.4 & 6.4 & 13.2 \\
$48 \mathrm{hr}(\mathrm{B} / \mathrm{T}) \%$ & 2.3 & 4.9 & 7.0 & 13.3
\end{tabular}


検血清 $0.1 \mathrm{ml}$ の使用により約 $30 \mathrm{ng} / \mathrm{ml}$ の $\mathrm{Tg}$ 濃度が測定可能であるが，これは臨床応用上不十分であ りまた本法は標識 $\mathrm{Tg}$ の易変性のため再現性も良好ではなかった.

3） $\mathrm{Tg}$ 測定法 (直接法)

a) precoating の抗体濃度 (Fig. 7)

300，3,000，15,000倍の各稀釈血清を用いて, 各種濃度の Tg 添加時の標淮曲線を比較した. 15, 000倍, 3,000倍では十分な結合放射能量がみられず，300 倍で十分な結合放射能量を認めた。更に，100倍稀釈血清 を用いて検討したが，300倍稀橎血清と著差はなかった。

\section{b) second coating}

$2 \% \mathrm{BSA}, 6 \% \mathrm{BSA}$ 扣よび10\%正常ヒト血清で比較したが，アッセイ上特に差を認めなかった。したが って, 以後 $2 \% \mathrm{BSA}$ を用いた.

c) インキュベーション時間 (Table 2)

第 2 段階でのインキュベーション時間を 24 時間と一定にして, 第 1 段階でのインキュベーション時間を16 時間と24時間で比較した. Table 2 の1)に示す如く，24時間のインキュベーションが感度，結合\%の何れ

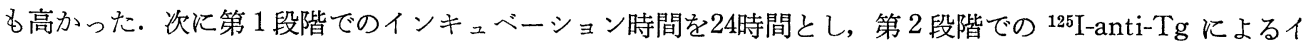
ンキュベーション時間につき，6，12，24および48時間で検討した. Table 2 の 2)に示す如く，時間とと もにバックグランドおよび結合放射能量は増加するが，24時間以後の増加は僅かであり，24時間が至適と考 えられた.

\section{d) ${ }^{125}$ I-anti-Tg 量の検討 (Fig. 8)}

${ }^{125} \mathrm{I}$-anti-Tg 量として, $10 \times 10^{4}, 20 \times 10^{4}$ ，拈よび $30 \times 10^{4} \mathrm{cpm} / \mathrm{cup}$ を用いての標準曲線に扣いては, $10 \times 10^{4} \mathrm{cpm} / \mathrm{cup}$ では十分な結合放射能量が得られず, 標準曲線もやや不安定であった. $30 \times 10^{4} \mathrm{cpm} / \mathrm{cup}$ では結合放射能量は上昇するが，B/T\%はさしろ低く, バックグランドも上昇し, 低濃度の $\mathrm{Tg}$ 測定が困

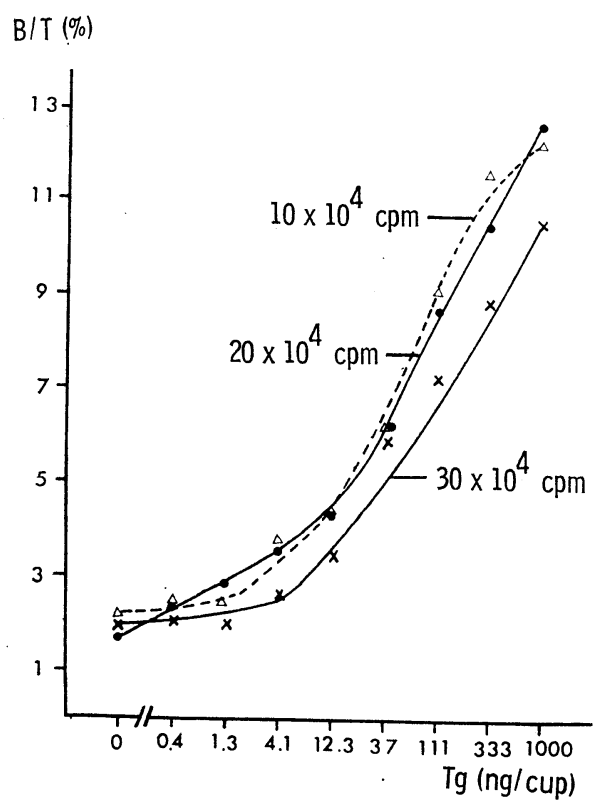

Fig. 8. Effect of different counts of ${ }^{125} \mathrm{I}-$ anti-Tg on the standard curve for Tg.

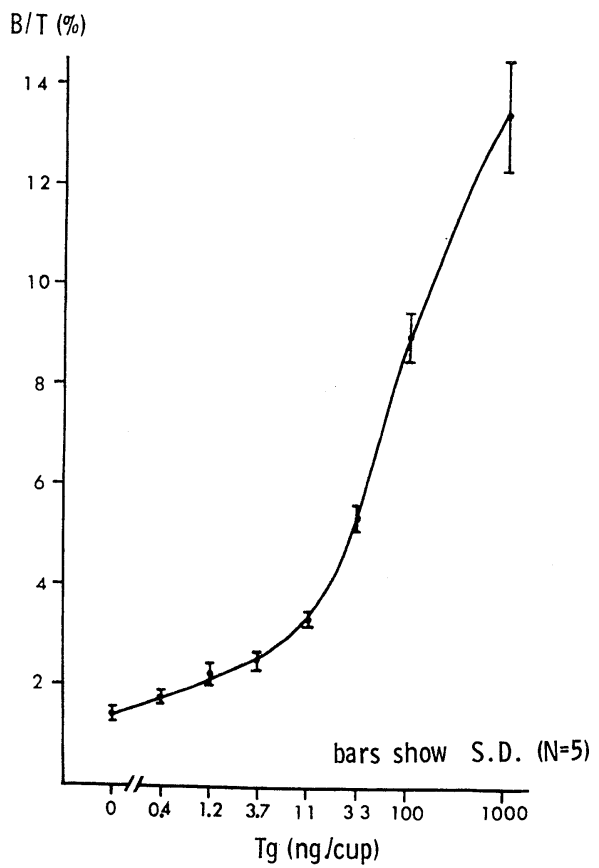

Fig. 9. Standard curve for Tg (Direct method). 
難である. $20 \times 10^{4} \mathrm{cpm} / \mathrm{cup}$ では B/T\%が高く, 標準 曲線も安定して扣り, 至適と考号られた。

\section{e) 標準曲線}

上記の基礎的検討に基づき，300 倍稀釈血清を抗体 として用い，2\%BSA で second coating し，第 1 段階で種々濃度標準 $\mathrm{Tg}$ を24時間インキュベイトし， 第 2 段階では ${ }^{125} \mathrm{I}$-anti-Tg の $20 \times 10^{4} \mathrm{cpm} / \mathrm{cup}$ を加 えて, 再び24時間インキュベイトして, Fig. 9 の標準 曲線を得た. 最少検出感度は $0.4 \mathrm{ng} /$ cup であった。

\section{f）稀釈曲線}

バセドウ病手術直後の症例の高濃度 $\mathrm{Tg}$ 血清の稀 釈曲線はFig. 10 に示す如く, よく標準曲線に平行し, キャリア蛋白として $2 \% \mathrm{BSA}$-PBS 液の使用が適当 と考えられた.

\section{g）回収試験（Table 3)}

正常者およびバセドウ病患者血清（サイロイド・テ スト陰性）では添加 Tg はほぼ良好な回収成積を示 した。一方, 橋本病で沈降抗体陽性例では回収率が悪

く，期待值より低值を示した。

\section{h) 血中Tg に対する anti-Tg の影響}

anti-Tg 存在下に拈ける $\mathrm{Tg}$ 值の意義を検討する ため, 各種濃度の anti-Tg・IgG を標準 Tg あるいは

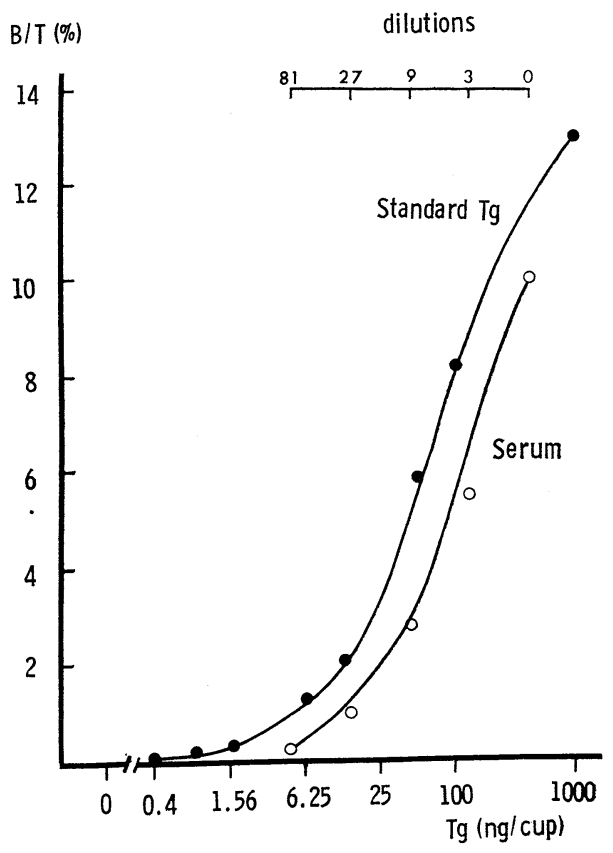

Fig. 10. Comparison of effects of dilution of purified $\mathrm{Tg}$ and of high $\mathrm{Tg}$ serum.

Table 3. Recovery of standard Tg added in various human sera

Added Tg concentration (ng/cup)

\begin{tabular}{c|cccccc|cc} 
& 1.9 & 7.5 & 15 & 30 & 60 & 600 & Mean & S. D. \\
\hline (Tg; $; .2 \mathrm{ng} / \mathrm{cup})$ & $83 \%$ & $82 \%$ & $83 \%$ & $82 \%$ & $91 \%$ & $118 \%$ & $89.8 \%$ & \pm 14.2
\end{tabular}

Added $\mathrm{Tg}$ concentration (ng/cup)

\begin{tabular}{c|cccccc|cc} 
& 2.5 & 7.5 & 22 & 66 & 200 & 600 & Mean & S. D. \\
\hline $\begin{array}{c}\text { Hshimoto's } \\
(\mathrm{Tg} ;<1.2 \mathrm{ng} / \mathrm{cup})\end{array}$ & $100 \%$ & $64 \%$ & $80 \%$ & $55 \%$ & $49 \%$ & $64 \%$ & $68.7 \%$ & \pm 18.6 \\
$\begin{array}{c}\text { Graves' } \\
(\mathrm{Tg} ;(37 \mathrm{ng} / \mathrm{cup})\end{array}$ & $100 \%$ & $100 \%$ & $102 \%$ & $104 \%$ & $107 \%$ & $145 \%$ & $109.7 \%$ & \pm 17.5
\end{tabular}

高 $\mathrm{Tg}$ 患者血清と $4^{\circ} \mathrm{C}$, 48時間，インキュベイトしたものについて，Tg のアッセイを行なった.

Fig. 11 飞添加 anti-Tg・IgG 量と測定された Tg 量を示す.サイロイド・テスト陰性の橋本病特よびバ セドウ病血清に少量の antii-Tg・IgG の添加では測定值に大きな変動はないが，あるレベルに特いて，一 過性に高値に傾き，更に anti-Tg・IgG 量の増加により Tg 量は直線的の低下を示した.この傾向は標準 Tgにおいても同様に認められた。

i ） トリヨードサイロニン $\left(\mathbf{T}_{3}\right)$ およびサイロキシン $\left(\mathbf{T}_{4}\right)$ の交叉反応に関する検討

Tg のアッセイ系に標準 Tg の代りに $T_{3}(0.002 \sim 2 \mathrm{ng} / \mathrm{cup}), \mathrm{T}_{4}(1.25 \sim 25 \mathrm{ng} / \mathrm{cup})$ を加光た場合, ${ }^{125} \mathrm{I}-$ anti-Tg の結合放射能量の上昇は認められなかった.

また，標準 $\operatorname{Tg}(10,100 \mathrm{ng} / \mathrm{cup})$ に $\mathrm{T}_{3}(0.1 \sim 10 \mathrm{ng} / \mathrm{cup})$ または $\mathrm{T}_{4}(4 \sim 100 \mathrm{ng} / \mathrm{cup})$ を加えた場合，そ 
の影響は認められなかった。

4) 各種甲状腺疾患者の Tg 値 (Fig. 12)

好条件下では $4 \mathrm{ng} / \mathrm{ml}$ の測定が可能であったが， 時に不安定な測定值を示すことがあり $12 \mathrm{ng} / \mathrm{ml}$ 以上 を測定可能範囲とし, $12 \mathrm{ng} / \mathrm{ml}$ 以下は統計的に $0 \mathrm{ng} /$ $\mathrm{ml}$ として扱った。

正常者 : 25例中15例 $(60 \%)$ に測定され平均値は $26.5 \pm 26.5$ (S. D.) $\mathrm{ng} / \mathrm{ml}$ であり, $100 \mathrm{ng} / \mathrm{ml}$ 以上の 值を示すものはなかった.

単純性甲状腺腫：23例中12例 (52\%) が測定され， 平均值は $37.9 \pm 87.0$ (S. D.) $\mathrm{ng} / \mathrm{ml}$ であり 2 例に高 值が認められた.

バセドウ病 : 未治療バセドウ病患者 9 例の平均值は $324.3 \pm 517.8$ (S. D.) $\mathrm{ng} / \mathrm{ml}$ であり，3 例に高值を 認めた. 治療例 27 例の平均值は $71.0 \pm 138.6$ (S.D.) $\mathrm{ng} / \mathrm{ml}$ であり, 3 例に高值を認めた。

橋本病 : 36例中14例に測定された. サイロイド・テ スト陰性の 10 例の平均值は $172.5 \pm 314.5$ (S.D.) ng/ $\mathrm{ml}$ であり,この内 2 例が $600 \mathrm{ng} / \mathrm{ml}$ および $900 \mathrm{ng} /$ $\mathrm{ml}$ の高值を示した. サイロイド・テスト陽性例の 26 例の平均值は $5.6 \pm 10.3$ (S. D.) $\mathrm{ng} / \mathrm{ml}$ であり, 全

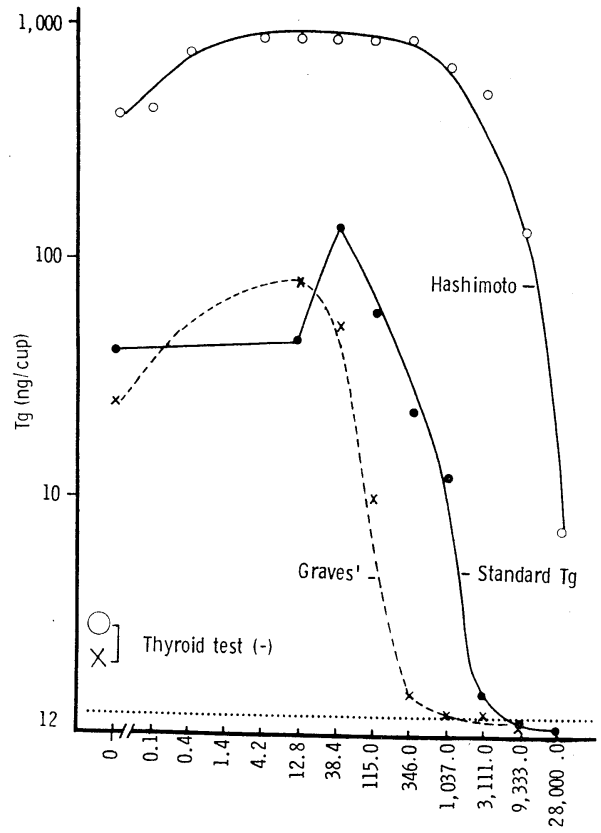

Add Anti-Tg IgG (ng/cup)

Fig. 11. Effect of anti-Tg IgG on the inhibition of binding of standard $\mathrm{Tg}$ or endogenous $\mathrm{Tg}$ in sera with coated anti-Tg.

T.T. : Thyroid test

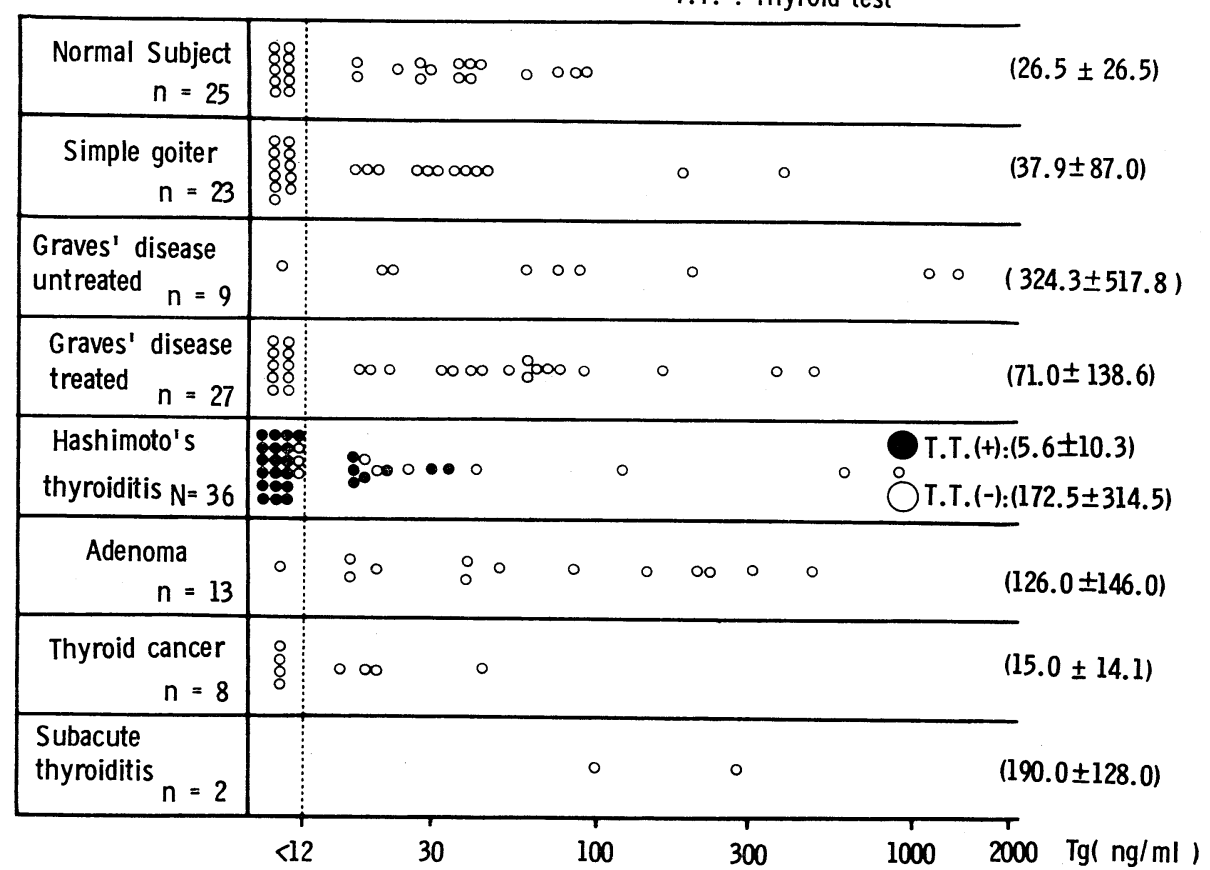

Fig. 12. Serum Tg concentrations in various thyroid diseases. 
例, 低值または正常範囲内にあって高値のものは認め られなかった。

甲状腺腺腫 : 13 例の平均值は $126.0 \pm 146.0$ (S.D.) $\mathrm{ng} / \mathrm{ml}$ であり, やや高值に分布した.

甲状腺癌：8例の平均值は $15.0 \pm 14.1$ (S.D.) ng/ $\mathrm{ml}$ であり, 低值を示した.

亜急性甲状腺炎：2 例に括いて，それぞれ, $280 \mathrm{ng} /$ $\mathrm{ml}$ 打よび $100 \mathrm{ng} / \mathrm{ml}$ と高值を示した.

5) バセドウ病, 甲状腺癌の術後の血中 $\mathbf{T g}$ 濃度 の観察 (Fig. 13)

術後約 1 週間の血中 $\mathrm{Tg}$ 濃度の観察では, バセド ウ病の 2 例で術直後 $16 \sim 30 \mu \mathrm{g} / \mathrm{ml}$ の異常高值が速か に下降したが, 術後 1 週間以後はゆるやかに減少し た. 甲状腺癌の 1 例では術直後 $340 \mathrm{ng} / \mathrm{ml}$ の高值を示 したが，それ以上には上昇せず, 以後も比較的高值が 持続した.

6) Tg 濃度と anti-Tg の関係 (Fig. 14)

橋本病およびバセドウ病共 anti-Tg 価の高いもの に Tg 濃度は低い傾向を示した $(r=-0.3)$.

サイロイド・テスト陰性例では橋本病, バセドウ病 共に高值を示すものがあったが, 低值のものも認めら

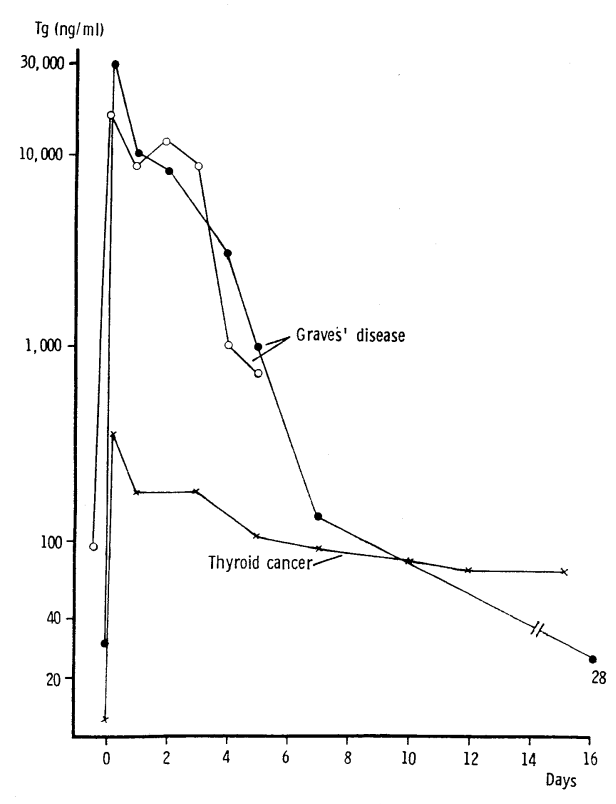

Fig. 13. Chronological changes in serum $\mathrm{Tg}$ level after partial thyroidectomy for Graves' disease.

\section{$\mathrm{Tg}(\mathrm{ng} / \mathrm{ml})$}

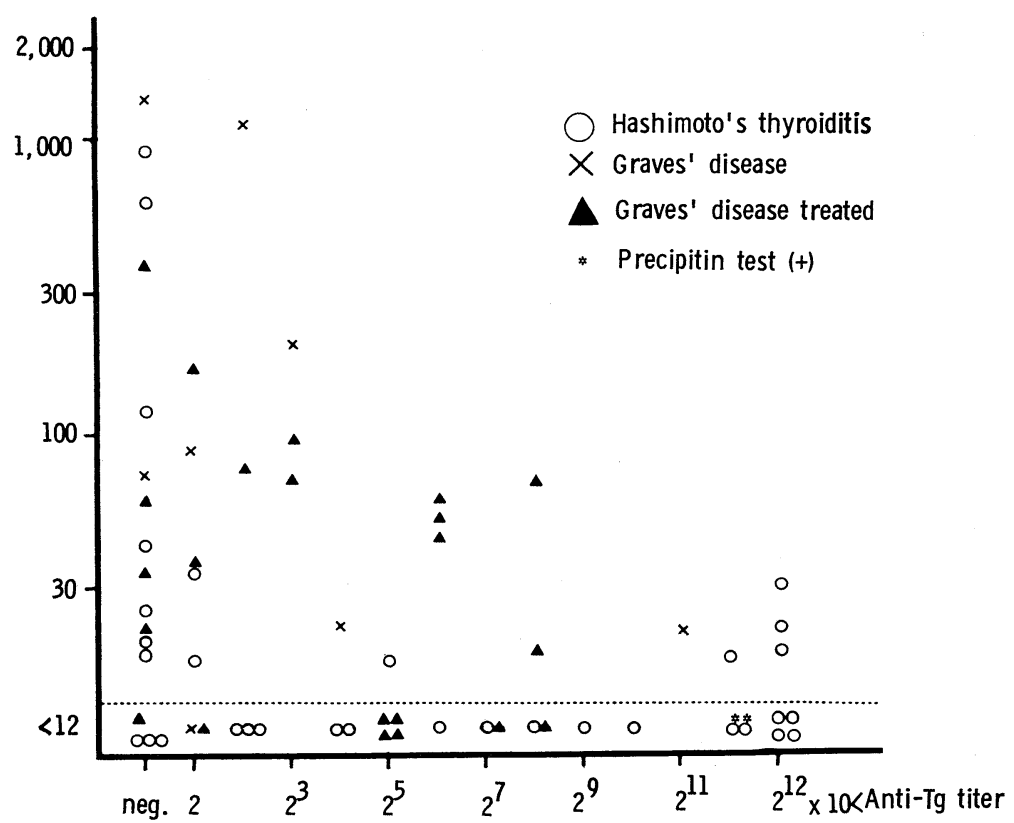

Fig. 14. Relation between serum Tg concentrations and anti-Tg titers in Hashimoto's thyroiditis and Graves' disease. 
れた. また，一方若干例に高抗体価を示しながらもな括有意の $\mathrm{Tg}$ 濃度を示すものが認められた。

7）バセドウ病における $\mathrm{Tg}$ 濃度と甲状腺機能検査成績

Fig. 15 はバセドウ病の $\mathrm{Tg}$ 濃度と血中 $\mathrm{T}_{3}$ 抌よび $\mathrm{T}_{4}$ 濃度との関係を示すが，一定の関係は認められ なかった。
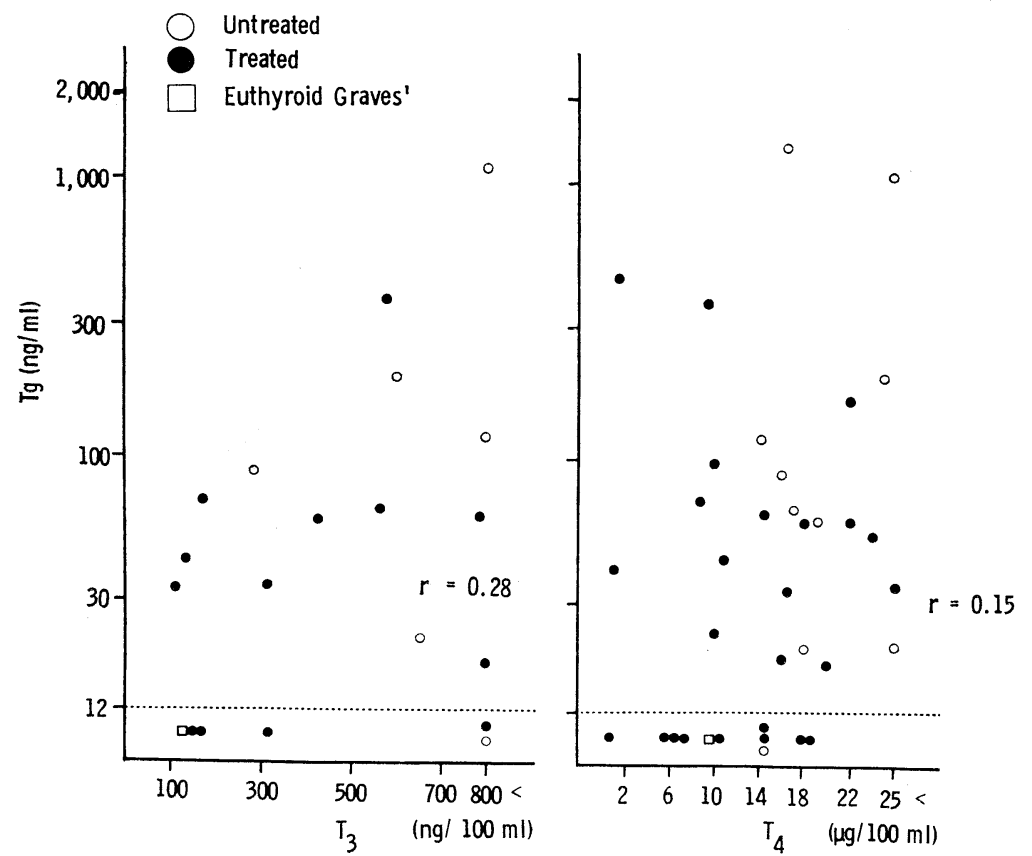

Fig. 15. Relation between serum $\mathrm{Tg}$ concentrations and serum thyroid hormone levels in Graves' disease.

\section{VI 考案}

血清中の $T g$ 量の測定に和いて, 従来の 2 抗体法 RIA では被検血清中に anti-Tg が存在する場合, 標 識 $\mathrm{Tg}$ はこれと結合するため $\mathrm{Tg}$ の測定が不能となり, したがって anti-Tg 陽性患者の Tg 測定は行な われていない。

著者は, anti-Tg 陽性患者の血中 $T g$ 濃度の測定を検討したものであり, 以下, 測定法, 測定成績に分 けて考案する.

1）測定法について

まず間接法 RIA により Tg の測定を試みたが, 最少検出濃度が $30 \mathrm{ng} / \mathrm{ml}$ で, 感度が低く, また ${ }^{125} \mathrm{I}-$ Tg の易変性のため再現性がそしかった。 また, この系においても被検血清に anti-Tg 含む場合, 従来 の 2 抗体法に怙けると同様 ${ }^{125} \mathrm{I}-\mathrm{Tg}$ と anti-Tg との結合が括こり, Tg の測定が不能と考えられたので直接 法による Tg の RIA を検討した。そそのためにはまず，精製 anti-Tgを得ることが必要となり，近年， 抗原扣よび抗体の精製に広く応用されている Immunoadsorbent18) 21)を用いて anti-Tg の精製を試みた. 溶出抗体中には $\mathrm{Tg}$ の混入を認めたため, これを更に抗体溶離液を用いてセファデックス G-200 に上るク ロマトグラフィを行ならことにより Tg を分離して, anti-Tg を精製した.

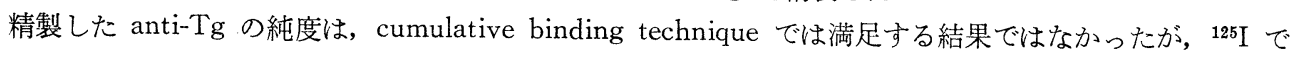


標識した精製 anti-Tg は大部分が Tg と結合することが確認でき, かなり純度の高い anti-Tg が得られた

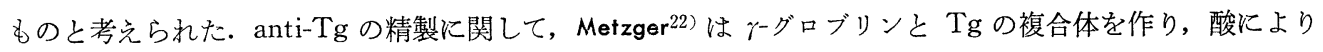

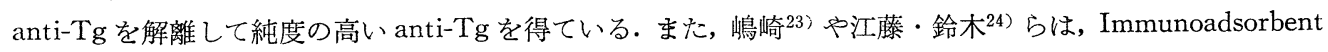
により anti-Tg の精製を試みているが, 純度に関しては詳細な検討が行なわれていない.

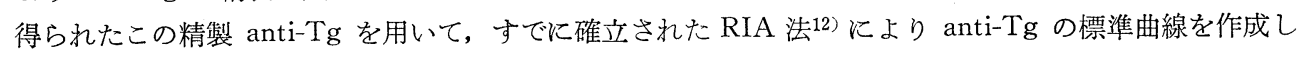
たが, Fig. 16 に示す如く, $30 \mathrm{ng} / \mathrm{cup}$ の抗体の測定が可能であり, 未精製の IgG を使用した場合に比較 して, 約10倍の感度の上昇が認められた. 更に抗体の純度が上昇すれば, その純定量が可能と考学られる.

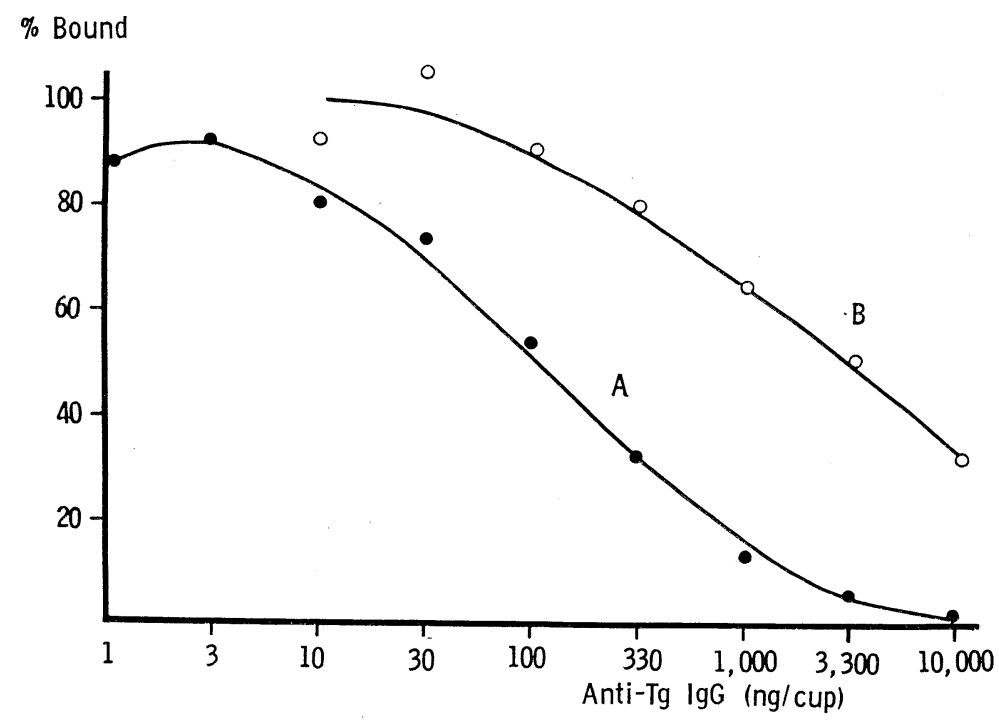

Fig. 16. Standard curve for anti-Tg.

Comparison of standard curve using purified anti- $\operatorname{Tg}(A)$ and $\operatorname{IgG}(B)$.

精製 anti-Tg を用いての直接法 RIA による Tg の測定法は簡便であり, 感度に関しても, Roitt, Torrigiani $\left.{ }^{10}, 11\right)$ らの $10 \mathrm{ng} / \mathrm{ml}$ に匹敵するものが得られた。この系では Tg の標識が不要であり, 標識 antiTgははるかに安定なため, 再現性が良好である利点をも認めた。

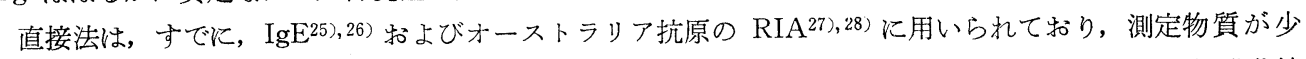
なくとも 2 個以上の免疫学的結合基を持つことが必須条件である. Tg に関して，カーブリニアの標潐曲線 を得たことは $\mathrm{Tg}$ が複数の抗体結合基を持つことを示唆し, $\mathrm{Tg}$ の結合基汇関する従来の知見 ${ }^{29)}$, 30) と一致 する.この系の特異性に関しては, 高 $\mathrm{Tg}$ 含有血清の稀釈曲線は標準曲線とよく平行し, anti- $\mathrm{Tg}$ にり $\mathrm{Tg}$ が吸収されること, 招よび $\mathrm{T}_{3}, \mathrm{~T}_{4}$ との間の交叉反応の認められないこと, 更には甲状腺手術直後では 異常高值を示すことから $\mathrm{Tg}$ に特異なアツセイ系と考えられる。しかしながら, anti-Tg の存在下では Tg の回収率は不十分であり, 正確なTg の測定が望めず, 更に今後の検索をまたねばならない. 回収率の不十 分な理由としては, 血中に $T g$ と anti-Tg が共存しうることから, 当然, Tg-anti-Tg 複合体の形成が考 えられる。Roitt29) 抢よび Schulman ${ }^{30)}$ らは橋本病血清に Tg を添加した場合の quantitative precipitin curue を示しているが，至適 $\mathrm{Tg}$ 量以外では複合体はいずれも減少する。したがって，anti-Tg を持つ血. 清では, 遊離 $\mathrm{Tg}$, anti-Tg 括よびその複合体が一定の平衡状態で共存しているものと考光られる.このよ らな血清に Tg を添加すればその平衡状態に变化を来たすことが想像され，添加 Tg が遊離 anti- $\mathrm{Tg}$ と結 合し, 回収の悪い結果を示したものと推定される. このことは多量の遊離 anti-Tg の存在下に怙いても, 
な扣複数抗体結合基を有する $\mathrm{Tg}$ が存在しらることを示唆していると考えられる. overby ${ }^{27)}$, 豊島 ${ }^{28)}$ も ーストラリア抗原特よび抗体の共存下で夫々が検出されることを認めている.

将来 Tg 特よび anti-Tg の純定量が可能となれば血中抗原量, 抗体量抏よび抗原抗体複合体の甲状腺自 己免疫機序の関与を分子レベルで解明されると期待される.

2）測定成績について

正常者25例中15例 $(60 \%)$ 飞g が測定され, $90 \mathrm{ng} / \mathrm{ml}$ までに分布し, 平均 $26.5 \mathrm{ng} / \mathrm{ml}$ であった. Torrigiani ${ }^{10)}$ は61\%に認め, $10 \sim 150 \mathrm{ng} / \mathrm{ml}$ の分布, Van Herle ${ }^{11)}$ は74\%に測定され, 平均 $5.1 \mathrm{ng} / \mathrm{ml}, 1.6 \sim$ $20.7 \mathrm{ng} / \mathrm{ml}$ の狭い範聿の分布の成績を報告している.Van Herle の成績の感度は良く，したがって検出 率も高いと思われるが, 正常域の異なる理由は不明である.

甲状腺腺腫では高值を示すものがあり，Torrigiani ${ }^{10)}$ bon toxic colloid goiter では甲状腺腫の大きさと の間に相関を認め, しばしば票胞を有することから血中への Tgの漏出が扣こるためと述べている．亚急性 甲状腺炎では，2 例共に高值を示したが，Torrigiani ${ }^{10)}$ は正常範囲，Van Herle ${ }^{11)}$ は高值を報告している. 本 症では急性期では当然組織の炎症破壞のため Tg の漏出が扣こり高值を示すものと思われる.

橋本病では Torrigiani ${ }^{10)}$ は16例の甲状腺抗体陰性例で 1 例の晎常高值 $(1200 \mathrm{ng} / \mathrm{ml})$ を除き $10 \sim 175 \mathrm{ng} / \mathrm{ml}$ の值を示した，著者の成績でもサイロイド・テスト陰性では低值から高值の広い範囲に分布し，異常高值を 示すものもあり，血中抗体の成立前に Tg の多量流出のあることを認めた. 一方サイロイド・テスト陽性例 に扣いても低值ながら Tgが測定されたが, 沈降抗体陽性の 2 例では, いずれも認められなかった。

バセドウ病では一般に Tg は高值を示すものがあり, Torrigiani, Van Herle も高値と報告している10), 11).

Tg はリンパ系を介して血中に出現する31),32),33)ことが知られて扣り，TSH 刺激によって Tg $\mathrm{T}_{4}$ と同様に反応を示し ${ }^{34)}$ ，しかも正常者で $\mathrm{T}_{3}$ による $\mathrm{Tg}$ 抑制が認められる事実 ${ }^{11)}$ がある. また $\mathrm{Tg}$ が ホルモン産生に極めて効率のよい蛋白である点 ${ }^{35)}$ を考兄合わせると両者の関係に興味が持たれる. Torrigiani は Tg 濃度と PBI 值の間に若干の関連性を認め, 治療後には Tg 濃度が低くなる傾向を示している10). 著者のバセドウ病の成績では $\mathrm{Tg}$ と $\mathrm{T}_{3}, \mathrm{~T}_{4}$ の間に明瞭な関係を認めず，また亜急性甲状腺炎，甲状腺腺 腫および橋本病で $\mathrm{Tg}$ 高值を示すものがあって, Tg と甲状腺ホルモンの間には明らかな関係は認められな かった.

\section{VII総括並びに結論}

plastic microtiter plate を用いた固相法 RIA による Tg の測定を試みた. 間接法では十分な感度, 再 現性がえられず，直接法による RIA を検討し，血中 Tg 濃度の測定を試みた. 本測定には anti-Tg の精 製が必要であり,これを Immunoadsorbent による affinity chromatography により精製した。成績は次 の通りである.

\section{1) affinity chromatography による anti-Tg の精製}

Cuatrecasas に準じ, Tg-Sepharose 4 B Immunoadsorbent を用いて anti-Tg を精製した. ${ }^{125} \mathrm{I}$ 標識精 製 anti-Tg は大部分が Tg と結合し，純度の高いものと考えられた.

\section{2）直接法による $\mathrm{Tg}$ の RIA}

標準曲線は $\mathrm{Tg}$ 量とともにカーブリニアに上昇し, $4 \mathrm{ng} / \mathrm{ml}$ の $\mathrm{Tg}$ 濃度の測定が可能であった. $\mathrm{T}_{3}$ およ び $\mathrm{T}_{4}$ とは交叉反応を示さず，高濃度 $\mathrm{Tg}$ 血清の稀釈曲線は標準曲線とよく平行した. しかし， anti-Tgを 有する血清に Tg を添加した場合の回収率は十分でなく, anti-Tg の存在下では Tg 量を正確には測定し 得なかった・しかしながらこの系に拈いて anti-Tg を有する患者血清に拈いて Tg が測定され得たこと から,この $\mathrm{Tg}$ 值は遊離 $\mathrm{Tg}$ 量を示すものと考えた.

\section{3）各種甲状腺疾患者の $\mathrm{Tg}$ 濃度}

正常者25例中15例 $(60 \%)$ 飞測定され, $0 \sim 90 \mathrm{ng} / \mathrm{ml}$ に分布し, 平均值 $26.5 \pm 26.5$ (S.D.) $\mathrm{ng} / \mathrm{ml}$, 単 純性甲状腺腫23例の平均值 $37.9 \pm 87.0$ (S. D.) $\mathrm{ng} / \mathrm{ml}$, 未治療バセドウ病 9 例の平均值 $324.3 \pm 517.8$ (S. D.) 
$\mathrm{ng} / \mathrm{ml}$, 治療バセドウ病 27 例の平均值 $71.0 \pm 138.6$ (S. D.) $\mathrm{ng} / \mathrm{ml}$, サイロイド・テスト陰性の橋本病10例 の平均值 $172.5 \pm 314.5$ (S. D.) $\mathrm{ng} / \mathrm{ml}$, サイロイド・テスト陽性の橋本病26例の平均値 $5.6 \pm 10.3$ (S.D.) $\mathrm{ng} / \mathrm{ml}$, 甲状腺腺腫13例の平均值 $126.0 \pm 146.0$ (S. D.) $\mathrm{ng} / \mathrm{ml}$, 甲状腺癌 8 例の平均值 $15.0 \pm 14.1$ (S.D.) $\mathrm{ng} / \mathrm{ml}$, であり, 亜急性甲状腺炎 2 例は夫々 $280 \mathrm{ng} / \mathrm{ml}$ および $100 \mathrm{ng} / \mathrm{ml}$, を示した。 またぐセドウ病 2 例の術後血中 $\mathrm{Tg}$ は $16 \sim 30 \mu \mathrm{g} / \mathrm{ml}$ の異常高値を示し, 甲状腺癌の 1 例では手術直後 $340 \mathrm{ng} / \mathrm{ml}$ を示した.

$\mathrm{Tg}$ 濃度と anti-Tg との関係は, サイロイド・テスト陰性例では Tg 濃度は低值から高值にまで分布し た. anti-Tg 高価のものに Tg 濃度は低い傾向を示し, 沈降抗体陽性では Tg は認められなかったが, anti- $\mathrm{Tg}$ 高值のものにも有意の $\mathrm{Tg}$ 量を示すものを認めた。 またバセドウ病にて $\mathrm{Tg}$ 濃度と血中 $\mathrm{T}_{3}$ 扰よ び $\mathrm{T}_{4}$ 濃度との間には一定の関係は認められなかった。

終りにのぞみ終始御想篤なる御指導と御校閲を頂いた恩師京大放射線科鳥塚莞爾教授に感謝の意を表しま す、また種々御助言を頂いた京大内科第 2 講座深瀬政市教授に深謝し，直接御教示戴いた放射線科森徽講師 および終始御協力下さった教室の甲状腺研究班の各位に感謝致します。

\section{文献}

1) Lerman, J. : J. Clin. Invest., $19: 555$, (1940). $\quad$ 2) Robbins, J. : J. Biol. Chem., $208: 377$, (1954). 3) Robbins, J., M. L. Petermann and J.E. Rall : J. Biol. Chem., 208: 387, (1954). 4) Owen, C.A. and W.M. McConahey : J. Clin. Endocr., $16: 1570$, (1956). 5) Hjort, T. : Lancet, $1: 1262$, (1961). $\quad$ 6) Hjort, T. and G. T. Pedersen : Lancet, $2: 259$, (1962).

7) Assem, E. S. K. : Lancet, $1: 139$, (1964). $\quad$ 8) Assem, E.S. K., W. R. Trotter and G. Belyavin : Immunology, $9: 21$, (1965). 9) Roitt, I. M. and G. Torrigiani : Endocrinology, $81: 421$, (1967). 10 ) Torrigiani, G., D. Doniach and I. M. Roitt : J. Clin. Endocr., 29 : 305, (1969). 11) Van Herle, A. J., R.P. Uller, N.L. Matthews and J. Brown : J. Clin. Invest., $52: 1320$, (1973). 12) Mori, T. and J. P. Kriss : J. Clin. Endocr., 33:688, (1971). 13) Rosenblatt, M. and M. Goodman : Am. J. Clin. Path., $39: 462$, (1963). 14) Sheidegger, J. J. : Int. Arch. Allergy. Appl. Immunol., $7: 103$, (1955). 15 ) Ouchterlony, O. : Prog. Allergy, $5: 1$, (1958). 16) Cuatrecasas, P., M. Wilchek and C. B. Anfinsen : Biochemistory, $61: 636$, (1968). 17 ) Greenwood, F. C., W. M. Hunter and J. S. Glover : Biochem. J., 89 : 114, (1963). 18) Wofsy, L. and B. Burr: J. Immunol., 103:380, (1969).

19) Avrameas, S. and T. Ternynck : Immunochemistry, $6: 53$, (1969).

20) Wilson, B. J., A. Malley, M. W. Cook and B.F. Mackler: J. Immunol., $106: 402$, (1971). 21) Haase, A. T. and H. G. Pereira : J. Immunol., $108: 633$, (1972). 22) Metzger, H. and H. Edelhoch : Nature, $193: 275$, (1962). $\quad$ 23) Shimazaki, M., K. Hamba, C. Hiramine, N. Katsu, T. Mori and Y.Keno : Wakayama Medical Reports, $11: 59,(1966) . \quad 24)$ 江藤澄哉, 鈴木秀郎 : ホルモンと臨床, $20: 62$, (1972). 25 ) Ceska, M. and U. Lundkvist: IMM., $9: 1021$, (1972). 26) Wide, L. : Radioimmunoassay Methods (Ed. by K. E. Kirkham and W. M. Hunter) p. 405,

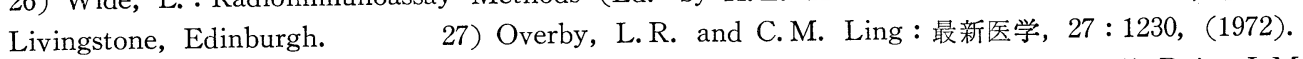
28）豊島 滋, 瀬戸頪子, 稻垣真理子, 富岡 一: 小児科臨床, $24: 3044,(1971)$. 29) Roitt, I. M., P. N. Campbell and D. Doniach : Biochem. J., 69:248, (1958). 30) Shulman, S. and E. Witebsky : J. Immun., 85 :559, (1960). 31) Daniel, P. M., M. M. Gale and O.E. Pratt : J. Physiol., 169:330, (1963). $\quad$ 32) Daniel, P. M., O.E. Pratt, I. M. Roitt and G. Torrigiani : Immunology, $12: 489$, (1967). 33 ) Daniel, P. M., O.E. Pratt, I. M. Roitt and G. Torrigiani : Quart. J. exp. Physiol., 52 : 184, (1967). 